\title{
Effects of Sodium Chloride on Some Physiological Traits and Chemical Composition of Two Safflower Cultivars
}

\section{HOSSEIN SADEGHI}

\author{
Department of Desert Region Management, College of Agriculture. Shiraz University, Shiraz, Iran.
}

\begin{abstract}
To investigate the effects of sodium chloride on two safflower cultivars (LRV 51/11 and LRV 51/51(padideh), four levels of salinity: $0,4,8$ and $12 \mathrm{dS} / \mathrm{m}$, were employed as a factorial experiment arranged in a randomized complete block design with four replication in a controlled environment of the greenhouse during 2008-2009. The desired salinity levels were developed by mixing the required amount of $\mathrm{NaCl}$ in soil before filling the pots $(0,2.16$, $4.32,8.64 \mathrm{~g} / \mathrm{kg}$ soil). In most southern provinces of Iran, Soil Salinity is a growing problem particularly in irrigated agricultural areas and has been found to reduce safflower yield. The results indicated that increasing salinity from 0 to 12 $\mathrm{dS} / \mathrm{m}$, decreased emergence percentage, significantly. The two cultivars responded similarly to salinity. The number of leaves per plant and also the plant height were decreased upon increasing salinity. The results showed that increasing salinity levels decreased leaf area (LA) and dry weight (DW) in the LRV 51/11 line. These two lines were not significantly different from each other with respect to LA, DW and $\mathrm{Na}^{+}$. Increasing salinity levels increased $\mathrm{Na}^{+}$and decreased $\mathrm{K}^{+}$in both varieties. Overall, it appeared that LRV51/11 has higher performance and better compatibility conditions to the region, it more suitable for growth in saline soils found in the investigation. Increasing salinity from 0 to $4 \mathrm{dS} / \mathrm{m}$ initially increased LA and DW but increasing salinity from 4 to $12 \mathrm{dS} / \mathrm{m}$ decreased LA and DW in the LRV 51/51(padideh) line. @ JASEM
\end{abstract}

Key words: Sodium chloride, leaf area, dry matter, Proline, $\mathrm{K}^{+}, \mathrm{Na}^{+}$.

Safflower (Carthamus tinctorius L.) is considered to be a moderately salt-tolerate crop (Bassil and Kaffka. 2002 and Maas, 1986) and has been grown in the most southern provinces of Iran for many years in conditions where salts restrict the growth of many other crops (Kaffka and Kearney, 1998). While generally regarded as tolerant, safflower yield also have been reduced by high levels of soil salts (Bassil and Kaffka. 2002). In most southern provinces of Iran, Salinity is a growing problem particularly in irrigated agricultural areas with rising water tables, poor water quality and/or deficient soil drainage. Soil salinity has been found to reduce safflower yield usually when values of electrical conductivity are above 6 deci siments per meter $(\mathrm{dS} / \mathrm{m})$ throughout the root zone (Arshi et al., 2002).

The use of saline water on safflower has diverse effects. It is reported to be more sensitive to salinity at germination than at later growth stages, because salinity reduces the rate and percent emergence at levels lower than those affecting plant growth (Francois et al., 1989). Typically, salt-affected safflower plants are smaller, more succulent with thickened and darker green leaves (Bassil and Kaffka. 2002). Stem diameter and plant height also are reported to decrease with increasing salinity (Gau et al., 2010). Transpiration rates are lowered, leaf cell structure is altered, and stomatal numbers are reduced (Bassil and Kaffka. 2002). Flowering and maturity can be hastened (Francois et al., 1994). Sometimes, intermediate levels of salinity (Albassam, 2001) as well as small amounts of sodium (Flores et al., 2001) appear to increase yield by favorably affecting harvest index. Genotypic variation to salinity tolerance has also been reported (Knowles, 1989). Other factors that affect safflower's tolerance to salinity include climate, weather, irrigation, soil conditions and fertility ( Robbelen et al., 1989 and Kaffka and Kearney, 1998).

Safflower is one of a few crops well suited to the cropping systems of the most southern provinces of Iran salt-affected soils. Most studies relevant to the most southern provinces of Iran were carried out several decades ago, and while they are generally still valid, new tests within the most southern provinces of Iran would be valuable, particularly under saltaffected conditions. Here, we present results on the effects of saline conditions on safflower biomass, and chemical composition. The objective of this work is the effects of sodium chloride on some physiological traits and chemical composition two safflower cultivars.

\section{MATERIALS AND METHODS}

Site, Treatment application and Data collection: This experiment was conducted to evaluate the effects of sodium chloride at two new safflower lines (LRV 51/11 and LRV 51/51(padideh), and four levels of salinity: $0,4,8$ and $12 \mathrm{dS} / \mathrm{m}$. The desired salinity levels were developed by mixing the required amount of $\mathrm{NaCl}$ in soil before filling the pots $(0,2.16,4.32$, $8.64 \mathrm{~g} / \mathrm{kg}$ soil). Cultivars originally and therefore under the name Long Rosette Varamin 51 or LRV51 are identified. These cultivars recently "by Fars Agricultural Research Center were studied and culture have been introduced. The safflower crop was sown on 10 November 2008 and harvested on 10 march 2009. The experiment was carried out in a greenhouse at the college of agriculture, Shiraz university, Shiraz Iran $\left(52^{\circ} 46^{\prime} \mathrm{E}, 29^{\circ} 50^{\prime} \mathrm{N}\right.$, altitude $1810 \mathrm{~m}$ asl), $12 \mathrm{~km}$ north of Shiraz, on a Fine mixed, mesic Typic Calcixerpets soil with air temperature in the range of about 25 to $30{ }^{\circ} \mathrm{C}$ and light intensity in the range of about $600-1000 \mu \mathrm{mol} \mathrm{m} \mathrm{m}^{-2} \mathrm{~s}^{-2}$, and was conducted using as a factorial experiment arranged in 
a randomized complete block design with four replication. Soil properties, are shown in tables 1 . Pre-germinated seeds were sown in $5 \mathrm{~L}$ perforated plastic pots filled with fertilized $(50 \mathrm{~N}, 25 \mathrm{P}$ and $25 \mathrm{~K}$ $\mathrm{mg} \mathrm{kg}{ }^{-1}$ ) and were kept in concrete tanks filled with tap water according to Maas et al., (1986). The level of water was maintained at $3 \mathrm{~cm}$ below the soil surface for $2 \mathrm{~d}$. Ten seeds of each of the two cultivars were sown in each pot, thinned to five seedling. The pots were kept flooded thereafter for the duration of the experiment. Plants were harvested and threshed manually. Leaf area index measured at maximum plant height, when canopy cover was fully developed and still green (Denison and Russotti, 1997). Leaf area measured by (Leaf area meter) model $\Delta \mathrm{T}$-device and Measure of aerial dry weight of samples was placed in temperature oven $\left(75^{\circ \mathrm{C}}\right)$, to reach constant weight.

Sodium and potassium measurements: Dried samples at the harvesting date were ground to a fine powder and about $0.1 \mathrm{~g}$ was transferred to a test tube containing $10 \mathrm{~mL}$ of $0 \cdot 1 \mathrm{~N}$ acetic acid, and heated in a water bath at $80{ }^{\circ} \mathrm{C}$ for $2 \mathrm{~h}$. The extracted tissue was cooled at room temperature and left overnight, and then filtered using Whitman filter paper number 40 . Sodium and potassium concentrations were then determined using an atomic absorption spectrometer (Perkins Elmer, Norwalk, CT, USA).
Proline measurements: Fresh flag leaf tissue ( $0.5 \mathrm{~g})$ was ground in liquid nitrogen and then extracted in 20 $\mathrm{mL}$ of hot water for $30 \mathrm{~min}$ with moderate shaking. The homogenate was centrifuged at $5000 \mathrm{~g}$ for 10 min. The proline concentration was quantified using the ninhydrin acid reagent method as described by Bates et al. (1973) using L-proline as a standard.

Statistical analysis: Statistical analysis was performed for each parameter studied based on a randomized complete block design model with four replications using SAS software (SAS Inst., 1985). Means were separated by Duncan's Multiple Range Tests at $\mathrm{p} \leq 0.05$.

\section{RESULTS AND DISCUSSION}

The results indicated that increasing salinity from 0 to $12 \mathrm{dS} / \mathrm{m}$, decreased emergence percentage, significantly. The two cultivars responded similarly to salinity. The number of leaves per plant and also the plant height were decreased upon increasing salinity (Table 1). The results showed that with increasing salinity levels from zero to $12 \mathrm{dS} / \mathrm{m}$ leaf area LRV51/11 cultivar decreased. The lowest leaf $\left(77.1 \mathrm{~cm}^{2}\right)$ was observed at $12 \mathrm{dS} / \mathrm{m}$ that had significant differences with the other levels (Table 3 ). At LRV51/51 cultivar with increasing salinity from zero to $4 \mathrm{dS} / \mathrm{m}$ leaf area increased, but by increasing from 4 to 8 and $12 \mathrm{dS} / \mathrm{m}$ leaf area was reduced (Table 3).

Table1. Mean comparison of main and interaction effects of morphological traits.

\begin{tabular}{lccc}
\hline Treatments & Emergence $\%$ & No of leaves per plants & Plant height $(\mathrm{Cm})$ \\
\hline Cultivars & & & \\
$\left(\mathrm{V}_{1}\right)$ LRV51/11 & $58.58 \mathrm{~A}$ & $5.91 \mathrm{~A}$ & $30.46 \mathrm{~A}$ \\
$\left(\mathrm{~V}_{2}\right)$ LRV51/51 & $60.41 \mathrm{~A}$ & $6.66 \mathrm{~A}$ & $30.66 \mathrm{~A}$ \\
Salinity (dS/m) & & & \\
$\left(\mathrm{S}_{0}\right) \quad$ & $94.00 \mathrm{~A}$ & $13.83 \mathrm{~A}$ & $53.17 \mathrm{~A}$ \\
$\left(\mathrm{~S}_{1}\right) \quad$ & $93.67 \mathrm{~A}$ & $10.00 \mathrm{~A}$ & $44.67 \mathrm{~A}$ \\
$\left(\mathrm{~S}_{2}\right) \quad 8$ & $55.00 \mathrm{~B}$ & $3.33 \mathrm{~B}$ & $28.50 \mathrm{~B}$ \\
$\left(\mathrm{~S}_{3}\right) 12$ & $3.33 \mathrm{C}$ & - & - \\
$\mathrm{V}_{1} \mathrm{~S}_{0}$ & $92.67 \mathrm{~A}$ & $13.33 \mathrm{~A}$ & $48.33 \mathrm{AB}$ \\
$\mathrm{V}_{1} \mathrm{~S}_{1}$ & $94.00 \mathrm{~A}$ & $8.33 \mathrm{~B}$ & $48.33 \mathrm{AB}$ \\
$\mathrm{V}_{1} \mathrm{~S}_{2}$ & $47.67 \mathrm{C}$ & $2.00 \mathrm{CD}$ & $25.33 \mathrm{D}$ \\
$\mathrm{V}_{1} \mathrm{~S}_{3}$ & $0.00 \mathrm{E}$ & $0.00 \mathrm{D}$ & $0.00 \mathrm{D}$ \\
$\mathrm{V}_{2} \mathrm{~S}_{0}$ & $95.33 \mathrm{~A}$ & $14.33 \mathrm{~A}$ & $58.00 \mathrm{~A}$ \\
$\mathrm{~V}_{2} \mathrm{~S}_{1}$ & $93.33 \mathrm{~A}$ & $11.67 \mathrm{~A}$ & $41.00 \mathrm{BC}$ \\
$\mathrm{V}_{2} \mathrm{~S}_{2}$ & $61.33 \mathrm{~B}$ & $4.66 \mathrm{C}$ & $31.67 \mathrm{CD}$ \\
$\mathrm{V}_{2} \mathrm{~S}_{3}$ & $6.66 \mathrm{D}$ & - & - \\
\hline
\end{tabular}

Means at each column followed by similar letters are not significantly different (5\%).

+ No plants growth due to salinity

Results showed that with increasing salinity from zero to $12 \mathrm{dS} / \mathrm{m}$ amount of dry matter was reduced at LRV51/11, although only significant difference between levels 8 and $12 \mathrm{dS} / \mathrm{m}$ was observed (Table
3). At LRV51/51 cultivar with increasing salinity from zero to $4 \mathrm{dS} / \mathrm{m}$ dry matter increased and further increases in salinity levels result in reduced plant dry matter was the highest dry matter level $4 \mathrm{dS} / \mathrm{m}$ was 
obtained level with the rest indicate a significant difference (Table 2), similar trend of leaf area was observed. The results also showed that two safflower varieties did not significant differences in the effects of salinity on dry matter weight (Table 3). The results showed that increasing salinity levels in both cultivars increased $\mathrm{Na}^{+}$significantly between the different levels were for all (Table 2).

The correlation coefficient between leaf area and dry matter amount of potassium in this study, positive and high significant while the correlation coefficient between $\mathrm{Na}^{+}$, leaf area and dry matter is negative and significant (Table 3).

Reduced leaf area of applied $\mathrm{NaCl}$ probably due to the adverse effects of salt reduction is a leaf cell development (Flores, et al., 2001). The results also showed that the leaf area of two safflower varieties did not significant differences in all salinity levels (Table 2).Reasons for reduced leaf area can be impaired nutrient balance in soil and plant photosynthesis and increased respiration deficiency noted that causes disturbances in plant growth (Joshi and Naik 1980).

Table 2. Mean comparison of main and interaction effects of chemical composition and some physiological traits of two safflower cultivars

\begin{tabular}{lccccc}
\hline Treatments & Leaf area $\left(\mathrm{cm}^{2}\right)$ & Total dry weight (gr) & $\mathrm{K}^{+}(\mathrm{mmol} \mathrm{per} \mathrm{Kg})$ & $\mathrm{Na}^{+}(\mathrm{mmol} \mathrm{per} \mathrm{Kg})$ & Proline $(\mu \mathrm{g} / \mathrm{g})$ \\
\hline Cultivars & & & & & \\
$\left(\mathrm{V}_{1}\right) \mathrm{LRV} 51 / 11$ & $100.0 \mathrm{~A}$ & $0.91 \mathrm{~A}$ & $830.5 \mathrm{~B}$ & $716.2 \mathrm{~A}$ & $0.35 \mathrm{~A}$ \\
$\left(\mathrm{~V}_{2}\right)$ LRV51/51 & $105.8 \mathrm{~A}$ & $0.92 \mathrm{~A}$ & $880.0 \mathrm{~A}$ & $704.2 \mathrm{~A}$ & $0.34 \mathrm{~A}$ \\
Salinity $(\mathrm{dS} / \mathrm{m})$ & & & & \\
$\left(\mathrm{S}_{0}\right) \quad$ & $121.5 \mathrm{~A}$ & $1.00 \mathrm{~B}$ & $1100 \mathrm{~A}$ & $533 \mathrm{D}$ & $0.25 \mathrm{D}$ \\
$\left(\mathrm{S}_{1}\right) 4$ & $140.2 \mathrm{~A}$ & $1.18 \mathrm{~A}$ & $942 \mathrm{~B}$ & $619 \mathrm{~B}$ & $0.27 \mathrm{~B}$ \\
$\left(\mathrm{~S}_{2}\right) 8$ & $95.5 \mathrm{~A}$ & $0.87 \mathrm{C}$ & $744 \mathrm{C}$ & $763 \mathrm{~A}$ & $0.41 \mathrm{~A}$ \\
$\left(\mathrm{~S}_{3}\right) 12$ & $74.5 \mathrm{~B}$ & $0.70 \mathrm{C}$ & $635 \mathrm{D}$ & $926 \mathrm{~A}$ & $0.41 \mathrm{~A}$ \\
$\mathrm{~V}_{1} \mathrm{~S}_{0}$ & $132.8 \mathrm{Aa}$ & $1.10 \mathrm{Aa}$ & $1050 \mathrm{Ab}$ & $550 \mathrm{D}$ & $0.25 \mathrm{D}$ \\
$\mathrm{V}_{1} \mathrm{~S}_{1}$ & $128.5 \mathrm{Aa}$ & $1.07 \mathrm{Aa}$ & $924 \mathrm{Bb}$ & $658 \mathrm{Ca}$ & $0.26 \mathrm{~B}$ \\
$\mathrm{~V}_{1} \mathrm{~S}_{2}$ & $101.7 \mathrm{Aa}$ & $0.92 \mathrm{Aa}$ & $738 \mathrm{Cb}$ & $763 \mathrm{Ba}$ & $0.33 \mathrm{~A}$ \\
$\mathrm{~V}_{1} \mathrm{~S}_{3}$ & $77.1 \mathrm{Ba}$ & $0.75 \mathrm{Ba}$ & $610 \mathrm{Db}$ & $894 \mathrm{Ab}$ & $0.34 \mathrm{~A}$ \\
$\mathrm{~V}_{2} \mathrm{~S}_{0}$ & $110.2 \mathrm{Ba}$ & $0.90 \mathrm{Bb}$ & $1150 \mathrm{Aa}$ & $516 \mathrm{Db}$ & $0.29 \mathrm{D}$ \\
$\mathrm{V}_{2} \mathrm{~S}_{1}$ & $151.9 \mathrm{Aa}$ & $1.29 \mathrm{Aa}$ & $960 \mathrm{Ba}$ & $580 \mathrm{Cb}$ & $0.30 \mathrm{AB}$ \\
$\mathrm{V}_{2} \mathrm{~S}_{2}$ & $89.3 \mathrm{Aa}$ & $0.83 \mathrm{Ba}$ & $750 \mathrm{Ca}$ & $763 \mathrm{Ba}$ & $0.37 \mathrm{~A}$ \\
$\mathrm{~V}_{2} \mathrm{~S}_{3}$ & $71.8 \mathrm{Ca}$ & $0.25 \mathrm{Ca}$ & $660 \mathrm{Da}$ & $958 \mathrm{Aa}$ & $0.38 \mathrm{~A}$ \\
\hline
\end{tabular}

Means at each column followed by similar letters are not significantly different (5\%

The results showed that increasing salinity levels in both cultivars increased $\mathrm{Na}^{+}$significantly between the different levels were for all (Table 3 ). In a study by (Patil et al., 1989) with increasing salinity level of 1 to $12 \mathrm{dS} / \mathrm{m} \mathrm{Na}^{+}$showed a significant increase. Kingsbury et al., (1984) showed that the major difference between two lines of wheat was their response to specific ion effects, at the level of the organ, tissue, cell, and sub cellular entities. Superior compartmentation of toxic ions by the more salttolerant line, presumably in the vacuole, might have enabled it to maintain its cytoplasmic metabolic apparatus in a stabler and more nearly normal state than the sensitive line was able to do; a measure of true cytoplasmic toleration of salt may also be a factor. The first phase of the growth response results from the effect of salt outside the plant. The salt in the soil solution (the 'osmotic stress') reduces leaf growth and, to a lesser extent, root growth (Munns, 1993). Salts themselves do not build up in the growing tissues at concentrations that inhibit growth, as the rapidly elongating cells can accommodate the salt that arrives in the xylem within their expanding vacuoles. So, the salt taken up by the plant does not directly inhibit the growth of new leaves.

The second phase of the growth response results from the toxic effect of salt inside the plant. The salt taken up by the plant concentrates in the old leaves; continued transport of salt into transpiring leaves over a long period of time eventually results in very high $\mathrm{Na}^{+}$and $\mathrm{Cl}^{-}$concentrations, and the leaves die. The cause of the injury is probably due to the salt load exceeding the ability of the cells to compartmentalize salts in the vacuole. Salts then would rapidly build up in the cytoplasm and inhibit enzyme activity. Alternatively, they might build up in the cell walls and dehydrate the cell (Flowers et al., 1991), but Mühling and Läuchli (2002) found no evidence for this in maize cultivars that differed in salt tolerance. The results showed that two varieties of safflower did not significant difference in $\mathrm{Na}+$ shoot (Table 3 ). 
According to the opinion of (Patil et al., 1989) safflower varieties contain less $\mathrm{Na}^{+}$in leaves are higher than with tolerance and salinity have a significant negative correlation between grain yield and sodium in leaves.

Increasing salinity from zero to $12 \mathrm{dS} / \mathrm{m}$ shoot potassium levels increased in both cultivars, the similar results reported with the other researchers (Patil.et al., 1989). The increase in $\mathrm{Na}^{+}$and $\mathrm{Cl}^{-}$and decrease in $\mathrm{K}^{+}$contents of wheat grains in both treatments suggest that the effect of salinity on the physiological phenomenon studied is due to changes in the ionic content of the plants. (Abdullah et al., 1978). Increasing salinity from zero to $12 \mathrm{dS} / \mathrm{m}$ shoot potassium levels increased in both cultivars, the similar results reported with the other researchers (Patil.et al., 1989). The increase in $\mathrm{Na}^{+}$and $\mathrm{Cl}^{-}$and decrease in $\mathrm{K}^{+}$contents of wheat grains in both treatments suggest that the effect of salinity on the physiological phenomenon studied is due to changes in the ionic content of the plants. (Abdullah et al., 1978).

Table 3. Correlation coefficient of chemical composition and some physiological traits of two safflower cultivars

\begin{tabular}{|c|c|c|c|}
\hline Traits & Leaf area & Dry weight & $\mathrm{Na}+$ \\
\hline $\mathrm{DW}$ & $0.937 * *$ & & \\
\hline $\mathrm{Na}+$ & $-0.575^{* *}$ & $-0.777^{* *}$ & \\
\hline $\mathrm{K}+$ & $0.580^{* *}$ & $0.466^{*}$ & $-0.844 * *$ \\
\hline
\end{tabular}

There is a strong correlation between salt exclusion and salt tolerance in many species (reviewed by Läuchli, 1984; Munns and James, 2003). The data shows the relationship between leaf $\mathrm{Na}^{+}$ concentration and salt tolerance. Salt tolerance was assessed as shoot dry matter after nearly 4 weeks of salt treatment In general; low- $\mathrm{Na}^{+}$genotypes had fewer injured leaves, and a greater proportion of living to dead leaves. The effect on growth was probably due to a better carbon balance in the genotypes with less $\mathrm{Na}^{+}$. A similar relationship between shoot dry matter and leaf $\mathrm{Na}^{+}$was found in a population from a cross between high- and low- $\mathrm{Na}^{+}$ genotypes. There was a strong correlation between shoot dry matter production and $\mathrm{Na}^{+}$concentration in leaves between families from a cross between the genotypes with the highest and lowest $\mathrm{Na}^{+}$also reported by (Munns and James, 2003).

The results showed that there was a significant difference among different salinity levels for proline content of the two cultivars. The proline content was also increased by increasing the salinity level in both cultivars (Table 3). Moradi and Ismail (2007) reported that it has been repeatedly inferred, but not yet proven, that there might be a relationship between salt tolerance and the accumulation of proline and other metabolites for osmotic adjustment. However, the present results suggest that the increase in proline concentration may not be associated with salinity tolerance, which agrees with similar observations made previously .However, elevated proline levels may also confer additional regulatory or osmoprotective functions under salt stress, such as its role in the control of the activity of plasma membrane transporters involved in cell osmotic adjustment in barley roots. Given the fact that proline biosynthesis is a highly energy-demanding process and that only small quantities of proline are probably required for the control of plasma membrane transporters (Cuin and Shabala, 2005),

Other approaches to improving salt tolerance in wheat are based on mechanisms for salt tolerance, using physiological traits to select germplasm.. Overall we can say that although the two varieties (LRV51/11 and LRV51/51) had not significant differences in leaf area, dry matter and sodium content, but according to the opinion of the other Researchers that showed LRV51/11 has higher performance and better compatibility conditions to the region, it more suitable for growth in saline soils found in the investigation.

\section{REFERENCES}

Abdullah, Z. Ahmad, R., and Ahmad J. 1978. Salinity induced changes in the reproductive physiology of wheat plants. Plant and Cell Physiol.19:99-106.

Arshi, A., A.Z. Abdin, and M. Iqbal. 2002. Growth and metabolism of senna as affected by salt stress. Biol. Plant. 45:295-298.

Bassil, E. S and S. R. Kaffka. 2002. Response of safflower (Carthamus tinctorius L.) to saline soils and irrigation: II. Crop response to salinity . Agricultural Water Management.54:81-92.

Colmer TD, Epstein E, Dvorak J. 1995. Differential solute regulation in leaf blades of various ages in salt-sensitive wheat and salt tolerant wheat x Lophopyrum elongatum (Host) A. Löve amphiploid. Plant Physiology.108:17151724.

Cuin TA, Shabala S. 2005. Exogenously supplied compatible solutes rapidly ameliorate $\mathrm{NaCl}$ induced potassium efflux from barley roots. Plant and Cell Physiology. 46:1924-1933. 
- Flores, P., M. Carvajal, A. Cerda, and V. Martinez. 2001. Salinity and ammonium/nitrate interactions on tomato plant development, nutrition, and metabolites. J. Plant Nutr. 24:15611573.

Guo, R., L. Shi, X, Ding, Y., Hu, S.,Tiang, D., Yan, S., Shao, Y., Gao, R., Liu and Y., Yang.2010. Effects of Saline and Alkaline Stress on Germination, Seedling Growth, and Ion Balance in Wheat. Agronomy Journal 102: 4: 1252-1260

Joshi, G. V., and, G. R. Naik. 1980. Response of sugarcane to different types of salt stress. Plant Soil. 56: 255-263.

Maas, E.V., 1986. Salt tolerance of plants. Appl. Agric. Res. 1, pp. 12-26.

Moradi F., and Ismail M. 2007. Responses of Photosynthesis, Chlorophyll Fluorescence and ROS-Scavenging Systems to Salt Stress during
Seedling and Reproductive Stages in Rice. Annals of Botany .99(6):1161-1173

Mühling K.H, Läuchli A. 2002. Effect of salt stress on growth and cation compartmentation in leaves of two plant species differing in salt tolerance. Journal of Plant Physiology 159, 137-146.

Munns R, and James RA. 2003. Screening methods for salt tolerance: a case study with tetraploid wheat. Plant and Soil. 253, 201-218.

Patil, B.C., Rao, M. R. G. Parama, V. R. P., and D. P. Vishwanth, 1989. Relative salt tolerance of safflower genotypes based on yield, sodium, Potassium and calcium contents. Indian J. Plant Physiol. 32(1): 90-94.

SAS Institute. (1985). SAS users guide . Statistics. Version 5 ed. SAS Inst., Cary, NC., USA. 